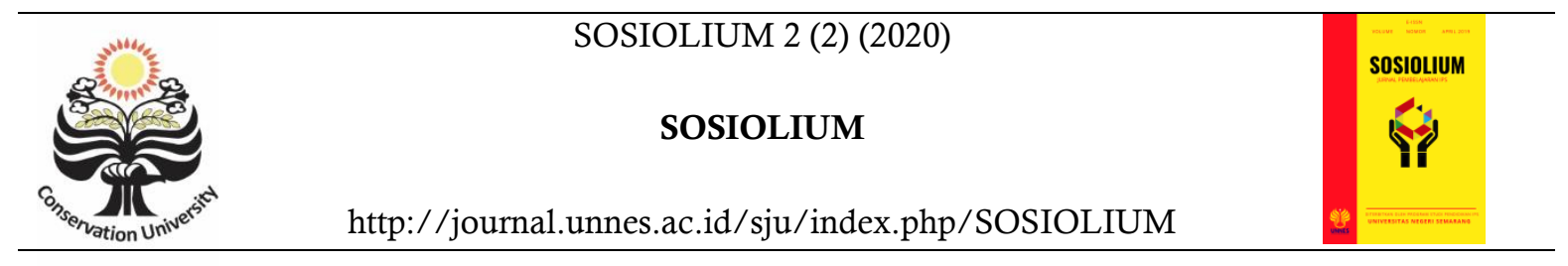

\title{
SIKAP DAN KETERAMPILAN SOSIAL DALAM MENERIMA KEBUDAYAAN BARU PADA MASYARAKAT PESISIR KECAMATAN AYAH KABUPATEN KEBUMEN
}

Erfina Ayu Wulandari, Arif Purnomo, Fredy Hermanto ${ }^{\bowtie}$

Prodi Pendidikan IPS, Fakultas Ilmu Sosial, Universitas Negeri Semarang, Indonesia.

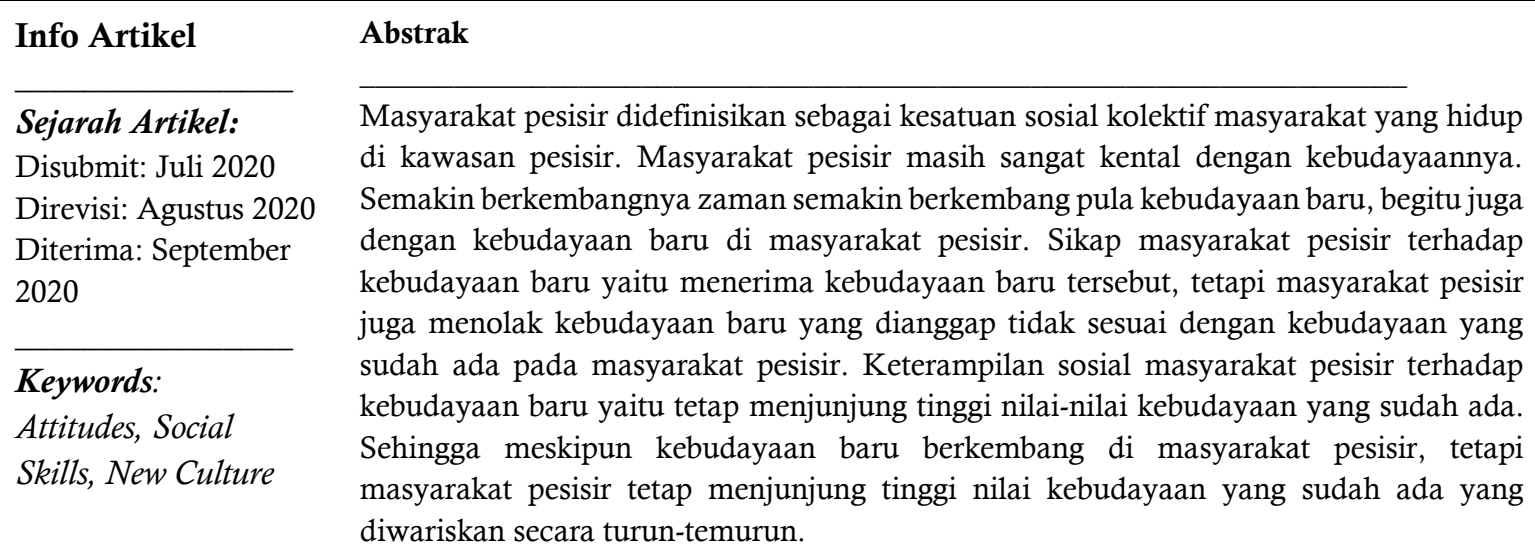

Abstract

Coastal societies are defined as the unity of collective social people living in coastal areas. Coastal societies are still very thick with their culture. As time goes by, the times are growing so that lead to the development of new cultures, including the new culture in coastal societies. The attitudes of the coastal societies towards the new culture are to accept the new culture, but the coastal societies also reject new cultures that are deemed incompatible with the culture that already exist in coastal societies. The social skills of coastal societies towards a new culture are to keep upholding existing cultural values. So that, even though a new culture develops in coastal societies, coastal communities still keep upholding existing cultural values inherited from generation to generation.

(C) 2020 UniversitasNegeri Semarang

\footnotetext{
${ }^{\square}$ Alamat korespondensi:

Gedung C1, Lantai 1, FIS Unnes

Kampus Sekaran, Gunungpati, Semarang, 50229

Email: arifpurnomo@mail.unnes.ac.id
}

E-ISSN 2685-4929 


\section{PENDAHULUAN}

Sikap sosial sangat dibutuhkan untuk menjalin hubungan dengan orang lain dalam kehidupan sehari-hari. Sikap sosial merupakan suatu tindakan seseorang untuk hidup dalam masyarakatnya seperti saling membantu, saling menghormati, saling berinteraksi, dan sebagainya.

W.J. Thomas (dalam Ahmadi, 2007:149) memberikan batasan sikap sebagai suatu kesadaran individu yang menentukan perbuatanperbuatan yang nyata ataupun yang mungkin akan terjadi di dalam kegiatan-kegiatan sosial. Sikap sosial sangat perlu karena dapat menciptakan suasana hidup damai, rukun, nyaman, dan tentram. Sikap sosial merupakan tindakan yang dapat mengatasi masalah yang ada dalam masyarakat dengan berpikir secara bersama-sama Selain sikap sosial, keterampilan sosial juga sangat dibutuhkan oleh masyarakat, karena dengan keterampilan sosial masyarakat mampu hidup selaras, meminimalisir tanggapan, tanggapan negatif dan berusaha menimbulkan tanggapan positif dari masyarakat sekitar.

Suhartini (dalam Siska, 2004:18), "Keterampilan sosial merupakan bentuk perilaku, perbuatan dan sikap yang ditampilkan oleh individu ketika berinteraksi dengan orang lain disertai dengan ketepatan dan kecepatan sehingga memberikan kenyamanan bagi orang yang berada di sekitarnya". Masyarakat yang menguasai keterampilan sosial, diharapkan dapat menyesuaikan terhadap kebudayaan baru yang ada di masyarakat pesisir Kecamatan Ayah.

Handoyo (2007:61-64) Masyarakat memiliki berbagai pola hidup, di Indonesia secara garis besar terdapat empat pola hidup masyarakat masa lalu yang memiliki arti penting dilihat dari peranannya dalam pembentukan kepribadian bangsa. Keemapat pola hidup tersebut adalah pola hidup peramu, pola hidup petani ladang, pola hidup petani sawah, dan pola hidup masyarakat pesisir. Ciri kehidupan masyarakat pesisir yang menonjol adalah mobilitas masyarakat yang tinggi.

Secara geografis, kawasan pesisir terletak pada wilayah transisi antara darat dan laut.
Sebagian besar masyarakat yang hidup di wilayah tersebut disebut sebagai masyarakat nelayan. dalam konteks ini, masyarakat nelayan didefinisikan sebagai kesatuan sosial kolektif masyarakat yang hidup di kawasan pesisir dengan mata pencahariannya menangkap ikan di laut, yang pola-pola perilakunya diikat oleh sistem nilai budaya yang berlaku, memiliki identitas bersama dan batas-batas kesatuan sosial, struktur sosial yang mantap, dan masyarakat terbentuk karena sejarah sosial yang sama.

Secara sosiologis, karakteristik masyarakat pesisir berbeda dengan karakteristik masyarakat agraris karena perbedaan karakteristik sumber daya yang dihadapai. Nelayan menghadapi sumber daya yang hingga saat ini masih bersifat akses terbuka (open acces). Karakteristik sumber daya seperti ini menyebabkan nelayan mesti berpindah-pindah untuk memperoleh hasil maksimal, yang dengan demikian elemen resiko menjadi sangat tinggi. Kondisi sumber daya yang beresiko tersebut menyebabkan nelayan memiliki karakter keras, tegas dan terbuka.

Setiap masyarakat pasti memiliki kebudayaan karena masyarakat adalah orang yang hidup bersama yang menghasilkan kebudayaan. Tidak ada masyarakat yang tidak mempunyai kebudayaan dan sebaliknya tidak ada kebudayaan tanpa masyarakat sebagai wadah dan pendukungnya. E. B. Taylor menjelaskan di dalam sebuah masyarakat pastilah memiliki kebudayaan yang berbedabeda antara masyarakat yang satu dengan masyarakat yang lainnya. "Kebudayaan adalah kompleks yang mencakup pengetahuan, kepercayaan, kesenian, moral, hukum, adat, istiadat, dan lain kemampuan-kemampuan serta kebiasaan-kebiasaan yang didapatkan oleh manusia sebagai anggota masyarakat" (Soekanto, 2013:150).

Kebudayaan nelayan adalah sistem gagasan atau sistem kognitif masyarakat nelayan yang dijadikan referensi kelakuan sosial budaya oleh individu-individu dalam interaksi bermasyarakat. Kebudayaan ini terbentuk melalui proses sosio historis yang panjang dan kristalisasi dari interaksi yang intensif antara masyarkat dan lingkungannya. 
Kecamatan Ayah mempunyai wilayah luas yang langsung berbatasan dengan Samudera Hindia sehingga mempunyai potensi kelautan yang cukup besar. Mayoritas mata pencaharian masyarakat Kecamatan Ayah adalah sebagai nelayan dengan menggunakan alat-alat sederhana. Kabudayaan masyarakat pesisir Kecamatan Ayah juga masih sangat kental dengan adanya berbagai aturan-aturan yang harus dipatuhi karena sudah diwariskan secara turun-temurun.

Kebudayaan baru juga berkembang di masyarakat pesisir Kecamatan Ayah. kebudayaan baru tersebut secara tidak langsung berkembang di masyarakat karena kemajuan teknologi informasi dan komunikasi yang sangat pesat. Kebudayaan baru yang ada di masyarakat Pesisir Kecamatan Ayah membawa dampak bagi masyarakat, mulai dari unsur bahasa, sistem pengetahuan, organisasi sosial, sistem peralatan hidup dan teknologi, sistem mata pencaharian hidup, sistem religi, dan kesenian. Dampak tersebut ada yang positif dan ada yang negatif. Tujuan penelitian ini adalah untuk mengetahui bagaimana sikap dan keterampilan sosial dalam menerima kebudayaan baru pada masyarakat pesisir Keacamatan Ayah Kabupaten Kebumen.

Penelitian ini menggunakan metode penelitian kualitatif dengan pendekatan deskriptif. Metode deskriptif kualitatif digunakan untuk menghasilkan data deskriptif berupa kata-kata lisan dari individu-individu dan perilaku yang diamati.

Lokasi penelitian ditetapkan di Desa Ayah, Desa Argopeni, Desa Srati, dan Desa Pasir yang terletak di Kecamatan Ayah Kabupaten Kebumen. Informan utama pada penelitian ini yaitu tokoh masyarakat dan Kepala Desa yang ada di pesisir Kecamatan Ayah. Informan pendukung dalam penelitian ini yaitu nelayan.

\section{PEMBAHASAN}

Kebudayaan masyarakat pesisir Kecamatan Ayah

Masyarakat pesisir Kecamatan Ayah termasuk masyarakat pedesaan yang antara satu dengan lainnya memiliki hubungan kekeluargaan. Masyarakat pesisir Kecamatan
Ayah juga dikenal sebagai masyarakat yang masih sangat kental akan kebudayaan tradisionalnya. Mayoritas masyarakat pesisir Kecamatan Ayah bekerja sebagai nelayan, karena dekat dengan laut sehingga masyarakat pesisir Kecamatan Ayah menggantungkan hidup mereka dengan melaut.

Kebudayaan baru yang berkembang di masyarakat hampir disetiap unsur kebudayaan ada. Tiap-tiap unsur kebudayaan universal sudah tentu juga menjelma dalam ketiga wujud kebudayaan. Menurut C. Kluckhohn tujuh unsur kebudayaan yang dapat ditemukan pada semua bangsa di dunia adalah: Bahasa, Sistem pengetahuan, Organisasi sosial, Sistem peralatan hidup dan teknologi, Sistem mata pencaharian hidup, Sistem religi, Kesenian.

Pada unsur bahasa, berkembangnya bahasa gaul yang semakin berkemban di masyarakat pesisir tidak menjadikan masyarakat pesisir menjadikan bahasa gaul tersebut untuk menjadi bahasa sehari-hari. Masyarakat pesisir tetap menggunakan Bahasa Jawa dengan dialeg ngapak yang menjadi bahasa ibu bagi masyarakat Kebumen, selain Bahasa Jawa masyarakat pesisir juga menggunakan Bahasa Indonesia.

masyarakat pesisir Kecamatan Ayah tetap menggunakan Bahasa Ngapak, Bahasa Jawa, dan Bahasa Indonesia meskipun bahasa gaul sudah mulai berkembang. Meskipun bahasa yang sering digunakan masyarakat pesisir Kecamatan Ayah adalah Bahasa Ngapak, tetapi masyarakat pesisir tetap mengajarkan kepada generasi muda untuk menggunakan bahasa yang baik sesuai norma yang berlaku ketika berbicara dengan orang lain dan orang yang lebih tua. Dengan adanya kebudayaan baru tersebut tidak menjadikan masyarakat pesisir Kecamatan Ayah melupakan bahasa yang menjadi ciri khas masyarakat Kebumen, masyarakat pesisir Kecamatan Ayah juga tetap mentaati norma yang sudah berlaku terkait dengan penggunaan bahasa.

Pada unsur sistem pengetahuan, masyarakat pesisir sudah semakin maju dengan adanya kebudayaan baru. Dulu sebelum adanya kebudayaan baru masyarakat pesisir hanya bersekolah sampai tingkat SD, dan kemudian membantu orang tua mereka untuk melaut. 
Tetapi dengan berkembangnya zaman, kesadaran untuk bersekolah meningkat hingga SMA/SMK, bahkan sekarang banyak masayarakat pesisir Kecamatan Ayah yang melanjutkan sekolahnya hingga ke perguruan tinggi.

Dengan akses informasi yang lebih mudah didapat juga menyebabkan pengetahuan masyarakat pesisir terhadap dunia luar lebih terbuka. Dengan fasilitas pendidikan yang semakin mudah dijangkau dan masyarakat pesisir Kecamatan Ayah semakin mudah untuk mendapatkan pendidikan dengan bantuanbantuan dari pemerintah sehingga masyarakat pesisir terjamin pendidikannya. Dengan demikian pengetahuan masyarakat pesisir juga semakin berkembang.

Pada unsur organisasi sosial masyarakat pesisir sudah semakin sadar akan pentingnya sebuah organisasi sosial. Dengan adanya kebudayaan baru, tumbuh organisasi sosial yang ada di masyarakat. Tujuannya adalah untuk menampung aspirasi anggotanya dan menyelesaikan permasalahan-permasalahan yang ada di dalam anggotanya maupun yang ada di masyarakat. Dengan adanya kebudayaan baru di masyarakat terbukti dapat menumbuhkan organisasi sosial yaitu karang taruna dan rukun.

Organisasi sosial yang ada di masyarakat pesisir Kecamatan Ayah yaitu karang taruna dan rukun. Organisasi ini dibentuk untuk menyelesaikan masalah-masalah yang terjadi di masyarakat. Semakin berkembangnya zaman dan kebudayaan baru di pesisir Kecamatan Ayah semakin banyak juga permasalahanpermasalahan yang harus dihadapi. Dengan adanya dua organisasi ini mampu mengurangi permaslahan-permasalahan yang tejadi di masyarakat pesisir Kecamatan Ayah.

Organisasi sosial sangat diperlukan bagi masyarakat pesisir Kecamatan Ayah. Karena sebelum ada organisasi sosial masyarakat bertingkah laku tidak sesuai aturan yang menyebabkan sering terjadi permasalahan. Namun setelah adanya organisasi sosial kehidupan masyarakat pesisir Kecamatan Ayah semakin teratur. Sebelum adanya karang taruna pemuda desa hanya tongkrong-tongkrong di pinggir jalan sambil bermain handphone dan ada pula yang mabuk-mabukan. Tetapi setelah pemerintah desa mendirikan karang taruna dengan tujuan untuk mewadahi pemuda desa agar tidak terjerumus ke dalam perilaku negatif, pemuda desa yang tadinya hanya tongkrong lama-lama hilang dan digantikan dengan program karang taruna yaitu latihan volly setiap sore hari. Pada organisasi nelayan juga sangat memberi dampak positif bagi para nelayan. dengan adanya rukun sangat berguna untuk menyelesaikan permasalahan nelayan. Ketika ada permasalahan di lingkup nelayan, para nelayan menyelesaikan bersama dalam lingkup rukun tersebut. selain itu ketika dermaga dan tempat pelelangan ikan mengalami kerusakan rukun ini juga dengan cara bergotong royong membetulkan dan membersihkan dengan ikhlas.

Pada unsur peralatan hidup dan teknologi ini sangat besar dampaknya bagi masyarakat pesisir. Dibidang pertanian ketika dulu masyarakat masih menggunakan cangkul ataupun tenaga hewan untuk membajak dengan adanya kebudayaan baru petani dimudahkan dengan adanya traktor untuk membajak dan pupuk kimia yang lebih mudah didapat. Bagi nelayan kebudayaan baru yang dirasakan yaitu dengan adanya perahu motor dan GPS untuk memudahkan ketika melaut. Sebelum adanaya kebudayaan baru masyarakat pesisir hanya menggunakan alat seadanya yaitu perahu dayung. Ketika ditengah laut terjadi suatu hal, para nelayan hanya bisa menunggu nelayan lain yang lewat karena tidak ada GPS. Selain itu teknologi informasi dan komunikasi juga merupakan kebudayaan baru yang ada di masyarakat pesisir Kecamatan Ayah. Dengan adanya handphone masyarakat tidak perlu jauhjauh pergi ke wartel untuk berkomunikasi jarak jauh. Adanya internet juga sangat memudahkan untuk mencari informasi lebih luas tanpa harus ke warnet.

Pada unsur mata pencaharian hidup, mata pencaharian hidup masyarakat yang tiggal di pesisir Kecamatan Ayah adalah petani, buruh, pegawai negeri maupun swasta dan mayoritas sebagai nelayan. meskipun kebudayaan baru sudah semakin berkembang tetapi nelayan pesisir Kecamatan Ayah adalah nelayan yang masih bersifat tradisional. Dimana masyarakat pesisir masih menggunakan alat-alat sederhana dalam menangkap ikan. Selain itu nelayan di 
pesisir Kecamatan Ayah juga merangkap sebagai petani dan pembuat gula. Hal ini dikarenakan ada musim-musim tertentu nelayan sulit mendapatkan ikan, sehingga untuk mencukupi kebutuhan sehari-hari masyarakat bertani dan membuat gula.

Mayoritas masyarakat pesisir Kecamatan Ayah beragama Islam, selain itu masyarakat pesisir Kecamatan Ayah menganut agama Kristen dan Budha. Mayoritas masyarakat pesisir Kecamatan Ayah adalah orang NU jadi masyarakatnya selalu percaya dengan apa yang dikatakan oleh ulama. Tradisi-tradisi yang berhubungan dengan roh halus juga sangat kental pada masyarakat pesisir Kecamatan Ayah. tradisi-tradisi terhadap nenek moyang dan upacara adat selalu rutin dilaksanakan karena masyarakat pesisir percaya bahwa jika tradisi dan upacara adat tersebut mempunyai kekuatan magis dan ketika tidak dilakukan masyarakat akan mengalami konsekuensinya.

Unsur kesenian yang ada pada masyarakat pesisir Kecamatan Ayah masih didominasi oleh kesenian tradisional. Meskipun kesenian baru sudah semakin berkembang di pesisir Kecamatan Ayah tetapi Kesenian tradisional masih eksis sampai saat ini. Kesenian tradisional yang masih eksis yaitu kuda lumping, jamjaneng, dan wayang. Meskipun kesenian itu sudah mulai hilang akibat adanya kebudayaan baru tetapi masyarakat pesisir Kecamatan Ayah masih tetap melestarikannya. Cara masyarakat pesisir melestarikan kesenian tersebut adalah dengan melakukan pagelaran kesenian tradisional meskipun hanya satu tahun sekali atau pada acara-acara tertentu. Hal ini agar masyarakat pesisir tidak melupakan kesenian tradisional dengan semakin berkembangnya kesenian modern.

\section{Sikap masyarakat pesisir Kecamatan Ayah terhadap kebudayaan baru.}

Semakin berkembangnya zaman semakin berkembang pula kebudayaan baru pada masyarakat. Kebudayaan baru juga berkembang di masyarakat pesisir Kecamatan Ayah. Kebudayaan baru yang semakin berkembang di masyarakat pesisir Kecamatan Ayah menjadi sebuah tantangan bagi masyarakat bagaimana masyarakat pesisir menyikapi hal tersebut, karena kebudayaan baru mempunyai dampak positif serta dampak negatif bagi masyarakat.

Kebudayaan baru nyatanya telah berkembang di masyarakat pesisir Kecamatan Ayah. dengan adanya kebudayaan baru di masyarakat pesisir Kecamatan Ayah menyebabkan perubahan sikap masyarakat pesisir tehadap kebudayaan tersebut.

Aspek kognitif yaitu berhubungan dengan gejala mengenai pikiran, berupa pengetahuan, kepercayaan, atau pikiran yang didasarkan pada informasi yang berhubungan dengan objek. Semakin berkembangnya kebudayaan baru di masyarakat pesisir menyebabkan pengetahuan masyarakat pesisir semakin maju. Pengetahuan masayarakat pesisir pada segala bidang sudah semakin maju. Masyarakat pesisir pun menerima perkembangan tersebut karena masyarakat pesisir Kecamatan Ayah percaya bahwa Kebudayaan baru tersebut memberi dampak positif bagi mereka.

Aspek afektif menunjuk pada dimensi emosional dari sikap, emosi yang berhubungan dengan objek berwujud proses yang menyangkut perasaan-perasaan tertentu seperti senang, tidak senang, ketakutan, kedengkian, dan simpati. Masyarakat pesisir Kecamatan Ayah sangat senang ketika ada kebudayaan baru yang berkembang di masyarakat. Masyarakat merasa dengan adanya kebudayaan baru tersebut semakin memudahkan masyarakat dalam kehidupan sehari-hari, tetapi disisi lain masyarakat pesisir Kecamatan Ayah juga tidak senang terhadap dampak negatif yang mereka rasakan.

Aspek konatif yaitu melibatkan salah satu presdisposisi atau kecenderungan untuk bertindak terhadap objek. Masyarakat pesisir Kecamatan Ayah sangat senang ketika ada kebudayaan baru yang berkembang. Tetapi masyarakat pesisir tidak menerima semua kebudayaan baru yang masuk di Kecamatan Ayah. Ketika kebudayaan baru tersebut lebih membawa dampak negatif bagi masyarakat maka masyarakat pesisir Kecamatan Ayah menolak kebudayaan tersebut.

Kebudayaan baru sudah berkembang pada masyarakat pesisir Kecamatan Ayah. Salah satu hal yang perlu diperhatikan oleh masyarakat pesisir yaitu bagaimana keterampilan 
masyarakat pesisir dalam menerima kebudayaan baru. Masyarakat pesisir Kecamatan Ayah masih menjaga komunikasi secara langsung meskipun sudah ada kemajuan teknologi handphone. Kebudayaan baru alat telekomunikasi ini tidak menjadikan masyarakat pesisir Kecamatan Ayah meninggalkan kebudayaan lama tentang berkomunikasi secara langsung. Handphone hanya digunakan untuk berkomunikasi jarak jauh, ketika berkumpul masyarakat saling berkomunikasi tanpa bermain handphone. Masyarakat pesisir Kecamatan Ayah juga sangat menghargai orang yang ada di sekitarnya tidak peduli kenal atau tidak walaupun orang baru sekalipun mereka sangat menghargai.

Masyarakat pesisir Kecamatan Ayah berinteraksi dengan orang lain dengan sangat baik. Pesisir Kecamatan Ayah merupakan wilayah pariwisata dengan banyak pantai. Dengan demikian kawasan pesisir Kecamatan Ayah sering dikunjungi oleh pengunjung dari luar Kecamatan Ayah. Masyarakat pesisir Kecamatan Ayah mampu berinteraksi dengan baik meskipun dengan masyarakat luar. Masyarakat pesisir Kecamatan Ayah pun sangat mudah bersosialisasi dengan lingkungannya. Karena kawasan pesisir Kecamayan Ayah masih pedesaan menyebabkan interaksi antar masyarakat masih tetap terjaga.

Tidak semua kebudayaan baru diterima oleh masyarakat pesisir Kecamatan Ayah. Jika ada pendatang yang kemudian menetap tetapi cuek dan tidak mau menyapa meskipun dengan tetangganya maka akan ditegur oleh masyarakat setempat. Hal ini karena pendatang tersebut tidak menyesuaikan diri dengan kebudayaan yang berlaku di masyarakat pesisir Kecamatan Ayah.

Meskipun kebudayaan baru sudah berkembang tetapi tidak semua masyarakat menerimanya. Ketika sedang berada di tempat baru sebaiknya menyesuaikan dengan kebudayaan yang ada di tempat tersebut agar tidak diberikan sanksi oleh masyarakat setempat. Katerampilan sosial menunjukan perilaku yang baik di masyarakat, bertegur sapa, menerima kritik, sangat baik diterapkan dalam kehidupan bermasyarakat agar tidak memperoleh sanksi dari masyarakat.
Interaksi antar masyarakat pesisir Kecamatan Ayah masih terjaga meskipun sudah berkembang kebudayaan baru. Karena kawasan pesisir Kecamatan Ayah masih pedesaan maka antar masyarakat masih saling mengenal meskipun rumahnya jaraknya jauh. Masyarakat pesisir Kecamatan Ayah masih saling menghormati. Ketika berbicara sangat sopan meskipun dengan orang yang tidak dikenal. Tolong menolong dan gotong royong juga masih melekat pada masyarakat pesisir Kecamatan Ayah. Selain itu dalam menyelesaikan masalah masyarakat pesisir melakukannya dengan cara berdiskusi.

\section{SIMPULAN}

Berdasarkan hasil penelitian tentang sikap dan keterampilan sosial dalam menerima kebudayaan baru pada masyarakat pesisir Kecamatan Ayah dapat disimpulkan bahwa kebudayaan masyarakat pesisir Kecamatan Ayah Kabupaten Kebumen masih didominasi oleh kebudayaan lama yang diwariskan turun temurun oleh nenek moyang dan masih dilestarikan hingga sampai saat ini. Masyarakat pesisir Kecamatan Ayah sadar akan adanya kebudayaan tersebut sehingga masyarakat saling bekerja sama untuk melestarikan kebudayaan tersebut. Sedangkan kebudayaan baru yang ada pada masyarakat pesisir Kecamatan Ayah sudah semakin berkembang. Pada unsur bahasa, ilmu pengetahuan, kesenian, mata pencaharian terdapat kebudayaan baru didalamnya, tetapi tidak semua kebudayaan baru ditermia oleh masyarakat. Masyarakat selalu memilah mana yang sesuai dan bermanfaat bagi mereka, jika kebudayaan baru dianggap tidak sesuai maka masyarakat akan menolaknya.

Sikap masyarakat pesisir terhadap kebudayaan baru yang semakin berkembang adalah masyarakat tetap menerima kebudayaan baru tersebut tetapi yang sesuai dengan kebudayaan yang sudah ada. Meskipun sudah ada kebudayaan baru, masyarakat masih tetap menjungjung tinggi sikap yang diperoleh dari kebudayaan lama. Komunikasi secara langsung antar masyarakat dan tegur sapa masih tetap terjaga meskipun sudah berkembang teknologi komunikasi. Masyarakat juga senang dengan adanya kebudayaan baru tersebut karena ada 
yang memberi dampak posotif dan memudahkan masyarakat pesisir Kecamatan Ayah. disisi lain masyarakat juga tidak senang dengan dampak negatif dari kebudayaan baru yang ada di masyarakat pesisir Kecamatan Ayah.

Keterampilan sosial masyarakat peisisir terhadap kebudayaan baru juga semakin meningkat. Semakin berkembangnya kebudayaan baru masyarakat sadar akan dampak yang akan dihadapi. Maka dari itu masyarakat pesisir Kecamatan Ayah tetap menjaga nilai gotong royong, tolong menolong dan toleransi antar masyarakat. Wujud dari kesadaran itu adalah inisiatif masyarakat untuk membuat jadwal gotong royong membersihkan lingkungan di masing-masing desa. Kesadaran masyarakat terhadap toleransi juga sangat tinggi. Ketika ada perbedaan pendapat masyarakat menyelasaikannya dengan cara berdiskusi bersama. Bahkan sudah terstruktur apa permasalahan yang terjadi dan dimana permasalahan tersebut harus didiskusikan. Meskipun kebudayaan baru sudah berkembang di masyarakat pesisir Kecamatan Ayah, tetapi sikap dan keterampilan sosial masyarakat pesisir Kecamatan Ayah sudah baik. Dengan semakin berkembangnya kebudayaan baru tersebut masyarakat masih memegang teguh kebudayaan lama yang sudah ada di masyarakat.

\section{SARAN}

Berdasarkan hasil penelitian berjudul Sikap dan Keterampilan Sosial Masyarakat Pesisir dalam Menerima Kebudayaan Baru pada Masyarakat Pesisir Kecamatan Ayah Kabupaten Kebumen tahun 2019, saran yang ditujukan kepada Dinas kebudayaan dan pariwisata diharapkan dapat mendukung kebudayaan masyarakat pesisir Kecamatan Ayah. Dinas kebudayaan juga bisa membuatkan sebuah kegiatan yang berupa festival kebudayaan masyarakat pesisir Kecamatan Ayah ataupun parade kebudayaan masyarakat pesisir Kecamatan Ayah. Dengan demikian kebudayaan masyarakat pesisir Kecamatan Ayah tidak semakin tertinggal dengan adanya kebudayaan baru tersebut.

Pemerintah Kecamatan Ayah juga dapat mengadakan sosialisasi-sosialisasi terkait pentingnya sikap dan keterampilan sosial bagi masyarakat pesisir Kecamatan Ayah agar masyarakat bisa menyikapi kebudayaan baru tersebut dengan baik dan dapat membedakan mana yang mempunyai dampak positif dan bermanfaat serta mana yang berdampak negatif.

Selain itu Masyarakat hendaknya mampu lebih selektif terhadap dampak positif dan dampak negatif dari kebudayaan baru yang semakin berkembang. Selain itu masyarakat pesisir Kecamatan Ayah juga harus meningkatkan kegiatan-kegiatan yang dapat meningkatkan solidaritas serta hubungan baik antar warga mayarakat. Selain itu yang utama adalah masyarakat harus mempunyai sikap dan keterampilan sosial yang baik dengan adanya kebudayaan baru yang semakin berkembang di masyarakat pesisir Kecamatan Ayah Kabupaten Kebumen, sehingga masyarakat bisa membedakan antara dampak positif dan negatif dari kebudayaan baru tersebut.

\section{DAFTAR PUSTAKA}

Ahmadi, Abu. 2007. Psikologi Sosial. Jakarta: Rineka Cipta.

Handoyo, Eko, dkk. 2015. Studi Masyarakat Indonesia. Ombak: Yogyakarta.

Siska, Yulia. 2011. 'Penerapan Metode Bermain Peran (Role Playing) dalam Meningkatkan Keterampilan Sosial dan Keterampilan Berbicara Anak Usia Dini. Dalam Jurnal Edisi Khusus No.2, Agustus 2011.

Soekanto, Soerjono. 2013. Sosiologi Suatu Pengantar. Depok: Raja Grafindo Persada. 